\title{
Mapping Soil Erosion Risk: Using Remote Sensing and Gis
}

\author{
Balaji Waghmare ${ }^{1}$, Madan Suryawanshi ${ }^{2}$ \\ ${ }^{I}$ Department of Geography, Dr.BabasahebMarathwada University, Aurangabad [MS], India. \\ ${ }^{2}$ Department of Geography, Dr.BabasahebMarathwada University, Aurangabad [MS], India.
}

\begin{abstract}
This article discusses research in which the authors applied the Revised Universal Soil Loss Equation (RUSLE), remotesensing, and geographical information system (GIS) to the maping of soil erosion risk in Brazilian Amazonia. Soil map and soilsurvey data were used to develop the soil erodibility factor $(K)$, and a digital elevation model image was used to generate thetopographic factor $(L S)$. The cover-management factor $(C)$ was developed based on vegetation, shade, and soil fraction imagesderived from spectral mixture analysis of a Landsat Enhanced Thematic Mapper Plus image. Assuming the same climaticconditions and no support practice in the study area, the rainfall-runoff erosivity $(R)$ and the support practice $(P)$ factors werenot used. The majority of the study area has $K$ values of less than $0 \_2, L S$ values of less than 2_5, and $C$ values of less than 0_25.A soil erosion risk map with five classes (very low, low, medium, medium-high, and high) was produced based on the simplifiedRUSLE within the GIS environment, and was linked to land use and land cover (LULC) image to explore relationships betweensoil erosion risk and LULC distribution. The results indicate that most successional and mature forests are in very low andlow erosion risk areas, while agroforestry and pasture are usually associated with medium to high risk areas. This research implies that remote sensing and GIS provide promising tools for evaluating and mapping soil erosion risk in Amazonia.
\end{abstract}

Key Words: soil erosion risk; RUSLE; remote sensing; GIS.

\section{Introduction}

The adverse influences of widespread soil erosion on soil degradation, agricultural production, water quality,hydrological systems, and environments, have long been recognized as severe problems for human sustainability(Lal, 1998). However, estimation of soil erosion loss is often difficult due to the complex interplay of many factors,such as climate, land cover, soil, topography, and human activities. In addition to the biophysical parameters,social, economic, and political components also influence soil erosion (Ananda and Herath, 2003). Accurate andtimely estimation of soil erosion loss or evaluation of soil erosion risk has become an urgent task.Scientists have been involved in soil erosion research for a long time, and many models for soil erosion lossestimation have been developed (Wischmeier and Smith, 1978; Nearing et al., 1989; Adinarayana et al., 1999;D'Ambrosio et al., 2001; Veihe et al., 2001; Shen et al., 2003). Fullen (2003) summarized some keynote papersabout soil erosion in northern Europe, and Lal (2001) highlighted major empirical models for predicting soilerosion loss. In practice, the Universal Soil Loss Equation (USLE) and later the Revised Universal Soil LossEquation (RUSLE) has been the most widely used model in predicting soil erosion loss. The USLE was originallydeveloped for soil erosion estimation in croplands on gently sloping topography (Wischmeier and Smith, 1978).

The RUSLE has broadened its application to different situations, including forest, rangeland, and disturbed areas(Renard et al., 1997). Traditionally, these models were used for local conservation planning at an individualproperty level. The factors used in these models were usually estimated or calculated from field measurements.The methods of quantifying soil loss based on erosion plots possess many limitations in terms of cost,representativeness, and reliability of the resulting data. They cannot provide spatial distribution of soil erosionloss due to the constraint of limited samples in complex environments. So, mapping soil erosion in large areas isoften very difficult using these traditional methods.

The use of remote sensing and geographical information system (GIS) techniques makes soil erosion estimationand its spatial distribution feasible with reasonable costs and better accuracy in larger areas (Millward and Mersey,1999; Wang et al., 2003). For example, a combination of remote sensing, GIS, and RUSLE provides the potentialto estimate soil erosion loss on a cell-by-cell basis (Millward and Mersey, 1999). Boggs et al. (2001) assessed soilerosion risk based on a simplified version of RUSLE using digital elevation model (DEM) data and land-unitsmaps. Bartsch et al. (2002) used GIS techniques to interpolate RUSLE parameters for sample plots to determinethe soil erosion risk at Camp Wiliams, Utah. Wilson and Lorang (2000) reviewed the applications of GIS inestimating soil erosion, discussed the difficulty and limitations of previous research and identified that GISprovided tremendous potential for improving soil erosion estimation. Wang et al. (2003) used a sample ground dataset, Thematic Mapper (TM) images, and DEM data to predict soil erosion loss through geostatistical methods(i.e., collocated cokriging and a joint sequential cosimulation model). They showed that 
such methods providedsignificantly better results than using traditional methods. In general, remote-sensing data were primarily used todevelop the cover-management factor image through land-cover classifications (Millward and Mersey, 1999;

Reusing et al., 2000; Ma et al., 2003), while GIS tools were used for derivation of the topographic factor fromDEM data, data interpolation of sample plots, and calculation of soil erosion loss (Cerri et al., 2001; Bartsch et al.,2002; Wang et al., 2003).

In many situations, land managers and policy makers are more interested in the spatial distribution of soilerosion risk than in absolute values of soil erosion loss. Different approaches have been used to assess the soilerosion risk, including empirical erosion models (Boggs et al., 2001; Cerri et al., 2001; Bartsch et al., 2002), aranking method based on selected indicators such as percentage of bare ground, aggregate stability, organiccarbon, percentage clay, and bulk density (Shakesby et al., 2002), and qualitative erosion risk mapping based onthe combination of five factors (geology, soil, relief, climate, and vegetation) (Vrieling et al., 2002).Brazilian Amazonia has experienced high deforestation rates since the 1970s, with large areas of mature forestbeing converted to patches of different successional stages, agricultural lands, and pastures (Batistella et al., 2003). The deforestation has been recognized as a major cause of soil degradation through soil erosion and the changes inimportant climate and ecosystem components (Thiam, 2003). However, the evaluation of soil erosion riskwithin Brazilian Amazonia has not attracted sufficient scientific attention. This article explores this topic usinga simplified RUSLE based on the integration of remote sensing and GIS in the moist tropical region of theBrazilian Amazonia and examines the relationships between land use and land cover (LULC), and soil erosionrisks.

\section{Brief Description Of The Rusle}

The RUSLE represents how climate, soil, topography, and land use affect rill and interrill soil erosion caused byraindrop impact and surface runoff (Renard et al., 1997). It has been extensively used to estimate soil erosion loss, to assess soil erosion risk, and to guide development and conservation plans in order to control erosion underdifferent land-cover conditions, such as croplands, rangelands, and disturbed forest lands (Millward and Mersey, 1999; Boggs et al., 2001; Mati and Veihe, 2001; Angima et al., 2003).

\section{Evaluation Of The Soil Erosion Risk}

Six parameters are required for the soil erosion estimation, as described previously. Because this study focuses onthe evaluation of soil erosion risk, instead of estimation of actual soil erosion loss, the $\mathrm{R}$ and $\mathrm{P}$ factors were not

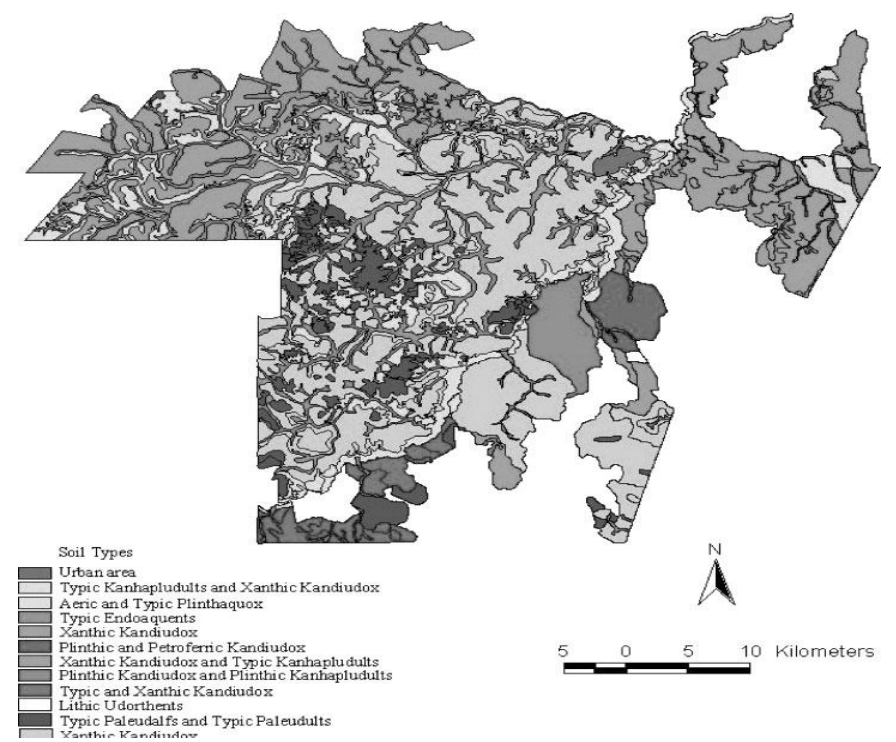

Figure 3. Spatial distribution of soil types within the study area.

Used, assuming that same climatic conditions and no support practices existed within the study area. So the soilerosion risk (SER) was developed based on K, LS, and C factors in a simplified equation: SER.K LS C.

\section{Development Of The K Factor Image}

The $\mathrm{K}$ factor is related to the integrated effects of rainfall, runoff, and infiltration on soil loss, accounting for theinfluences of soil properties on soil loss during storm events on upland areas (Renard et al., 1997). It is often 


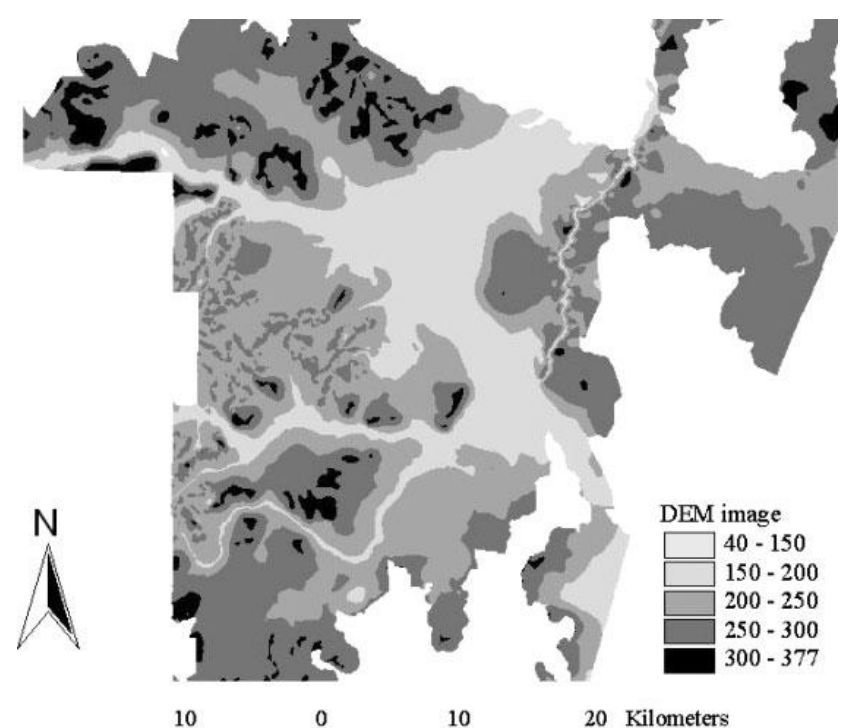

Figure 4. Grey-scale image illustrating elevation classes within the study area.

estimated through experimental equations (e.g., Equation 2) or corresponding nomographs (Wischmeier andSmith, 1978).The K value for each sample plot was calculated, then each soil type was associated with a $\mathrm{K}$ value assumingthat the same soil type has the same $\mathrm{K}$ value throughout the study area. Figure 6 illustrates the $\mathrm{K}$ factor distribution.It indicates that most of the study area has a $\mathrm{K}$ value of less than $0 \_2$.

\section{Development Of The Ls Factor Image}

The LS factor accounts for the effect of topography on erosion in RUSLE. The slope length factor (L) representsthe effect of slope length on erosion, and the slope steepness factor (S) reflects the influence of slope gradient onerosion. The common equation used for calculating LS is an empirical equation (see Equation 3) provided by theUSDA Agriculture Handbook (Wischmeier and Smith, 1978).

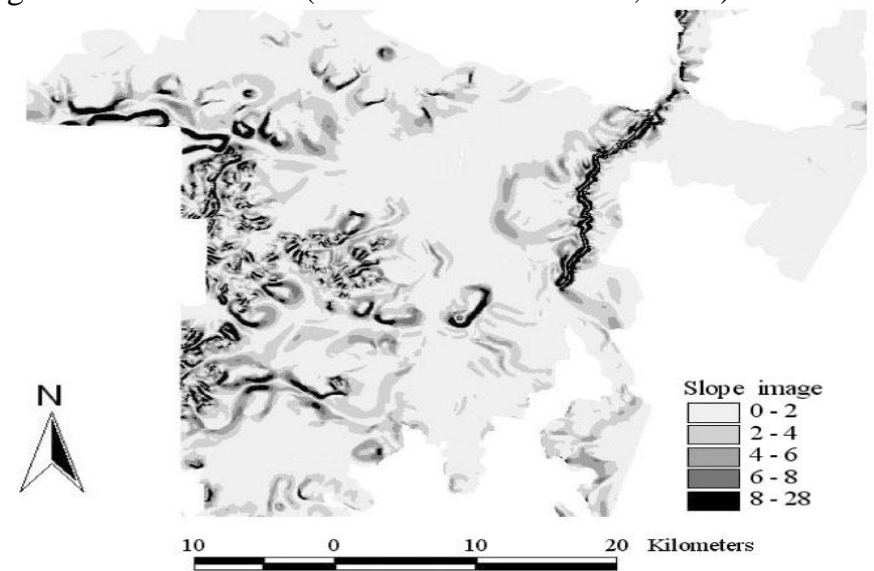

Figure 5. Grey-scale image illustrating slope classes within the study area.

\section{Development Of The C Factor Image}

The $\mathrm{C}$ factor reflects the effects of cropping and management practices on soil erosion rates in agricultural landsand the effects of vegetation canopy and ground covers on reducing the soil erosion in forested regions (Renardet al., 1997). Usually, the $\mathrm{C}$ factor is derived using empirical equations based on the measurements of manyvariables related to ground covers collected in the sample plots. The $\mathrm{C}$ factor values at non-sampled locations wereestimated through spatial interpolation techniques. This method is often timeconsuming and computer intensive.It only provides point values with limited locations. The interpolation results based on the $\mathrm{C}$ factor point values 


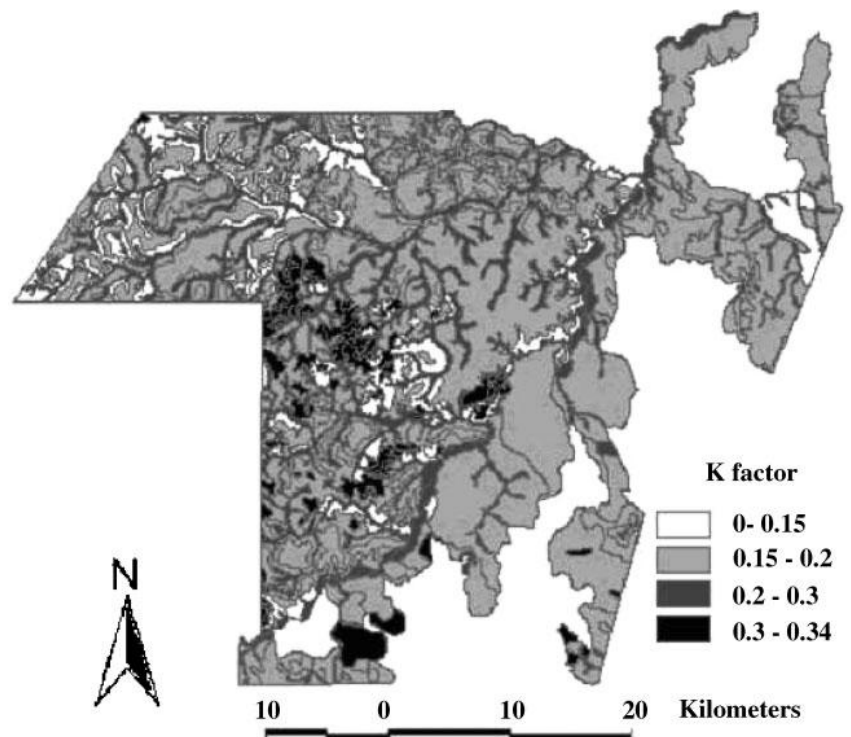

Figure 6. The soil erodibility factor developed from soil sample plots data and soil map.

Remotely sensed data have been used to estimate the $\mathrm{C}$ factor distribution based on land-cover classification results(Millward and Mersey, 1999; Reusing et al., 2000), assuming that the same land covers have the same $\mathrm{C}$ factorvalues. The result greatly depends on: (1) the details of land-cover classes and classification accuracy; and (2) thedetermination of a suitable $\mathrm{C}$ factor value for each class. However, the same land-cover class may have different Cfactors due to variations in vegetation density. In this study, the $\mathrm{C}$ factor was estimated (see Equation 4) based on the fraction images from spectral mixtureanalysis (SMA) of Landsat ETM. image, assuming that abundant vegetation cover associated with a complexstand structure results in less soil erosion loss, while more soil fraction associated with less vegetation cover resultsin higher soil erosion loss.

\section{Discussion And Conclusions}

RUSLE was originally developed for the USA, but also has been proven valuable for estimation of soil erosion lossin other regions of the world (Millward and Mersey, 1999; Reusing et al., 2000; Angima et al., 2003, Ma et al.,2003). In general, RUSLE is used for estimating average annual soil erosion loss based on sample plot data. Theuse of remote sensing and GIS allows us to map the spatial distribution of soil erosion risk. However, because remotely sensed data capture the surface characteristics at the time of the image acquisition, caution must be takenwhen developing the $\mathrm{C}$ factor image. Calibration of the results using reference data may be necessary if it is usedfor estimation of absolute soil erosion loss. Also, the use of multitemporal remotely sensed data may be necessaryto generate an average $\mathrm{C}$ factor image.Six parameters, derived from different data sources such as DEM, soil, climate, and remotely sensed data, areused in the RUSLE. The different data sources may have different data formats, projections, data quality, andspatial resolution. The use of GIS provides the tools to manage and analyze these data. However, the evaluation ofthese data is necessary before they are used. The uncertainties regarding data sources may introduce largeruncertainties in soil erosion estimates. Great attention should be paid to the evaluation and preprocessing of datasources, such as data interpolation, conversion, and registration.

\section{Mapping Soil Erosion Risk}

Estimation of soil erosion loss in a large area is often difficult, as well as its validation. Although this paperfocuses on the evaluation of soil erosion risk, validation using reference data is also valuable. For example, ifreference data are available, the classification of soil erosion risk and the identification of thresholds for each risklevel will be more appropriate.In summary, this study provides an approach for the evaluation of soil erosion risk in Brazilian Amazonia basedon a combination of RUSLE, remote sensing, and GIS. This is an effective way to map the spatial distribution ofsoil erosion risks in a large area. The methods and results described in this article are valuable for understandingthe relationship between soil erosion risk and LULC classes and are useful for managing and planning land usethat will avoid land degradation. For Brazilian Amazonia, such topics are very important due to current activities involving forest conversion to other land covers. 


\section{References}

[1] Adinarayana J, Rao KG, Krishna NR, Venkatachalam P, Suri JK. 1999. A rule-based soil erosion model for a hilly catchment. Catena 37:309-318.

[2] Ananda J, Herath G. 2003. Soil erosion in developing countries: a socio-economic appraisal. Journal of Environmental Management 68:343-353.

[3] Angima SD, Stott DE, O’Neill MK, Ong CK,Weesies GA. 2003. Soil erosion prediction using RUSLE for central Kenyan highland conditions.Agriculture, Ecosystems, and Environment 97: 295-308.

[4] Bartsch KP, van Miegroet H, Boettinger J, Dobrwolski JP. 2002. Using empirical erosion models and GIS to determine erosion risk at CampWilliams. Journal of Soil and Water Conservation 57: 29-37.

[5] Batistella M. 2001. Landscape change and Land-Use/Land-Cover dynamics in Rondônia, Brazilian Amazonia. CIPEC Dissertation Series,No. 7. Center for the Study of Institutions, Population, and Environmental Change (CIPEC), Indiana University: Bloomington, Indiana.

[6] Batistella M, Robeson S, Moran EF. 2003. Settlement design, forest fragmentation, and landscape change in Rondônia, Amazonia.Photogrammetric Engineering and Remote Sensing 69: 805-812.

[7] Boggs G, Devonport C, Evans K, Puig P. 2001. GIS-based rapid assessment of erosion risk in a small catchment in the wet/dry tropics of Australia. Land Degradation \& Development 12: 417-434.Bognola IA, Soares AF. 1999.

[8] Solos das 'glebas 01, 02, 03 e 06' do Municı'pio de Machadinhod'Oeste, RO. PesquisaemAndamento, No. 10.EmbrapaMonitoramentoporSate' lite: Campinas, Brazil, 7.

[9] Cerri CEP, Dematte JAM, Ballester MVR, Martinelli LA, Victoria RL, Roose E. 2001.

[10] GIS erosion risk assessment of the Piracicaba RiverBasin, southeastern Brazil. Mapping Sciences and Remote Sensing 38: $157-171$.

[11] D'Ambrosio D, di Gregorio S, Gabriele S, Gaudio R. 2001. A cellular automata model for soil erosion by water. Physics and Chemistry of theEarth, Part B: Hydrology, Oceans and Atmosphere 26: 33-39.

[12] Embrapa. 1999. Sistema brasileiro de classificac, a o de solos. Centro Nacional de Pesquisa de Solos: Rio de Janeiro.Fullen MA. 2003. Soil erosion and conservation in northern Europe. Progress in Physical Geography 27: 331-358.

[13] Goovaerts P. 1999. Using elevation to aid the geostatistical mapping of rainfall erosivity. Catena 34: 227-242.

[14] Hickey R. 2000. Slope angle and slope length solutions for GIS. Cartography 29: 1-8.

[15] INPE. 2002. Monitoring of the Brazilian Amazonia Forest by Satellite 2000-2001. Instituto Nacional de PesquisasEspaciais: Jose dos Campos,Brazil.

[16] Lal R. 1998. Soil erosion impact on agronomic productivity and environment quality: critical reviews. Plant Sciences 17: 319-464.

[17] Lal R. 2001. Soil degradation by erosion. Land Degradation \& Development 12: 519-539.

[18] Lemos RC, Santos RD. 1996. Manual de descric, a o e coleta de solos no campo, 3rd edn. SBCS/Embrapa-CNPS: Campinas, Brazil.

[19] Lu D, Moran E, Batistella M. 2003. Linear mixture model applied to Amazonian vegetation classification. Remote Sensing of Environment 87:456-469.

[20] Lu D, Mausel P, Batistella M, Moran E. 2004. Comparison of land-cover classification methods in the Brazilian Amazonia basin.Photogrammetric Engineering and Remote Sensing 70: 723-731.

[21] Ma JW, Xue Y, Ma CF,Wang ZG. 2003. A data fusion approach for soil erosion monitoring in the Upper Yangtze River Basin of China based onUniversal Soil Loss Equation (USLE) model. International Journal of Remote Sensing 24: 4777-4789. 